\title{
Unveiling superior cross combination in maize (Zea mays L.)
}

\author{
Shujaat Ali ${ }^{1}$, Shah Jehan Khan ${ }^{1}$, Arshad Jamil ${ }^{1 *}$, Asif Imran Shah ${ }^{2}$ and \\ Muhammad Waqas ${ }^{1}$ \\ 1. Faculty of Agriculture, Gomal University, Dera Ismail Khan-Pakistan \\ 2. Cotton Research Station, Ratta Kulachi, Dera Ismail Khan-Pakistan \\ *Corresponding author's email: arshadjamil99@yahoo.com \\ Citation \\ Shujaat Ali, Shah Jehan Khan, Arshad Jamil, Asif Imran Shah and Muhammad Waqas. Unveiling superior cross \\ combination in maize (Zea mays L.). Pure and Applied Biology. Vol. 6, Issue 2, pp676-684. \\ http://dx.doi.org/10.19045/bspab.2017.60071
}

Received: $25 / 02 / 2017$

Revised: $10 / 05 / 2017$

Accepted: 28/05/2017

Online First: 02/06/2017

\section{Abstract}

An experiment was conducted to find out the heterotic and heterobeliotic in maize during 2013-14 at Agricultural Research Institute, Dera Ismail Khan to get the superior cross combination expressing high hybrid vigour. The crosses were made in 2013 and $F_{1}$ hybrids along with their parents were studied in 2014. Six maize inbred lines viz; Islamabad-white, Buffa Selection I, Sahiwal-2002, Sadaf, Islamabad Gold and Azam were used and full diallel approach was adopted to get the superior cross combination and to unveil best cross combination. Data were recorded on days to $50 \%$ pollen shed, days to $50 \%$ silking, plant height, number of ears plant ${ }^{-1}$, ear length, number of kernel rows ear ${ }^{-1}$, number of kernel row $^{-1}, 1000$ kernel weight and grain yield $\mathrm{kg} \mathrm{ha}^{-1}$. The analysis of variance revealed that means squares due to progenies and their parents were highly significant for all the traits except number of kernels ear ${ }^{-1}$ and 1000 kernel weight which showed significant differences. Only number of kernels row ear ${ }^{-1}$ depicted non-significant variation. The analysis of variance (Table 1) showed that mean squares due progenies and parents were highly significant for all the traits. Twenty two crosses had positive heterosis ranged from $+0.84 \%$ (BS-1 x Sadaf) to $51.3 \%$ (Islamabad-white x Sadaf) for grain yield $\mathrm{kg} \mathrm{ha}^{-1}$. For days to $50 \%$ pollen shed, heterosis ranged from $(-10.8$ to $+0.6 \%)$. The twenty seven hybrids showed negative heterosis, while the two hybrids showed positive heterosis for days to 50\% silking. For plant height twenty seven crosses showed positive heterosis ranged from $(0.0 \%$ to $15.5 \%)$. The heterosis and heterobeltiosis for number of ears palnt ${ }^{-1}$ ranged from $(-11.5 \%$ to $16.0 \%),(-14.6$ to $+13.8 \%)$ respectively. For ear length heterosis ranged from $+0.12 \%$ (Islamabad-white $\mathrm{x}$ BS-1) to $+26 \%$ (BS-1 x Islamabad gold). Heterosis and heterobeltiosis ranged from $+2.5 \%$ (BS-1 x Islamabad-white) to $9.1 \%$ (Sahiwal-2002 x Islamabad white) and $4.7 \%$ (BS-1 x Azam) to $7.6 \%$ (Sahiwal-2002 x Islamabad-white) for number of kernel rows ear $^{-1} .1000$ kernel weight showed heterosis and heterobeltiosis ranged from +1.5 (BS-1 x Azam) to +19.5 $\%$ (Islamabad white x Sadaf) and $+0.2 \%$ (Azam x Islamabad white) to $19.2 \%$ (Islamabad white x Sadaf). Hence it is suggested that 3 parents viz; Islamabad Gold, Sahiwal 2002 and Sadaf can give promising yield if included in breeding experiments to unzip genetic configuration.

Keyword: Maize; Inbred lines; Heterosis and heterobeltiosis

\section{Introduction}

Maize (Zea mays L.) is an important cereal and ranks $3^{\text {rd }}$ amongst other cereal. It is cultivated in Pakistan on about 1.096 million hectares with a total annual production of
38.05 million tons [1]. Despite of higher yield potential we are lagging far behind the world in average yield on per unit area basis. By producing high yielding hybrids, we may increase average yield. Increasing 
population has also raised the edible oil consumption. Hence billions of rupees are needed to meet the requirements of population. Maize plays an important role in the economy of Pakistan. Maize is a naturally cross-pollinated crop and a high degree of heterotic effect can be utilized by crossing the inbred lines. The success of any improvement programme for the production of high yield, early maturity and better quality maize hybrids or synthetic varieties depend upon the identification and selection of local and exotic elite parents to be utilized in a breeding programme. Heterosis breeding is the key tool for the production of high yielding hybrids and better response to fertilizers. The ultimate aim of most plant breeding programs is to increase yield and quality of crops. Thus to ascertain best cross combination present research was conducted at the Agricultural Research Institute, Ratta Kulachi, Dera Ismail Khan.

\section{Materials and methods}

The present study was conducted to unveil superior cross combinations amongst thirty direct and reciprocal crosses, evolved from six parental inbred lines i.e., Islamabad White (Isl W), Buffa Selection I (BS-I), Sahiwal 2002 (S-2002), Sadaf, Islamabad Gold (Isl G) and Azam. The parental lines were sown in crossing block during 2013, and possible crosses were made according to complete diallel mating fashion, at experimental site of Agricultural Research Institute (ARI), Ratta Kulachi, Dera Ismail Khan, Pakistan. During 2014 season, the first filial generations ( $\mathrm{F}_{1}$ 's) were raised in a triplicated randomized complete block (RCB) design. The plot size maintained as single row of 5 meter length, with spacing's of $75 \mathrm{~cm}$ and $25 \mathrm{~cm}$ between rows and plants respectively. The data recorded from five guarded plants on various yield related parameters i.e., days to $50 \%$ tasseling, days to $50 \%$ silking, plant height at maturity $(\mathrm{cm})$, number of ears plant ${ }^{-1}$, ear length (cm), number of kernel rows ear-1, number of kernels row $^{-1}$, number of kernels ear ${ }^{-1}, 1000$-grains weight $(\mathrm{g})$, and grain yield $\left(\mathrm{kg} \mathrm{ha}^{-1}\right)$.

\section{Statistical analysis}

Heterosis and heterobetiosis was calculated in terms of percent increase (+) or decrease (-) of a hybrid against its mid and better parents.

Heterosis $(\mathrm{MP})=100 \mathrm{X}\left[\mathrm{F}_{1}-\mathrm{MP} / \mathrm{MP}\right],[2]$

Heterobetiosis $(\mathrm{BP})=100 \mathrm{X}\left[\mathrm{F}_{1}-\mathrm{BP} / \mathrm{BP}\right]$, [3]

MP = Mid Parent,

$\mathrm{BP}=$ Better Parent,

$\mathrm{F}_{1}=$ First Filial generation

The data were further subjected to " $t$ " test to determine whether $\mathrm{F}_{1}$ hybrids are different from mid and better parental values statistically. The " $t$ " value was calculated by the following formula as used by Fehr [4]

Where $\mathrm{t}=\mathrm{F}_{1}-\mathrm{MP}$

$$
\begin{gathered}
\sqrt{3} / 2 \mathrm{r}(\text { EMS }) \\
\mathrm{t}=\sqrt[\mathrm{F}_{1}-\text { B.P }]{\sqrt{2 / \mathrm{r}(\mathrm{EMS})}}
\end{gathered}
$$

$\mathrm{MP}=$ the mid parent value for the cross, $\mathrm{BP}=$ the better parent value for the cross,

$r=$ No. of replications,

EMS = Error mean square.

\section{Results and discussion}

\section{Days to $50 \%$ pollen shed}

Table 1, showed the means values for days to $50 \%$ pollen shed of parental lines and their respective direct and reciprocal hybrids $\left(F_{1}\right)$. Inbred lines ranged from 45.0 (Azam) to 51.7 (Sadaf),

The means calculated for the traits under study have been shown in Table 1 and heterosis and hetrobeltiosis have been shown in Table 2 . The negative heterosis are preferred in maize hybrid for days to pollen shed .The crosses showed negative heterosis over mid and better parental value, except Islamabad-gold $\mathrm{x}$ Islamabad-white, as shown in Table 1. The crosses showed 
negative heterosis MP ranging from $0.6 \%$ Islamabad-gold x Islamabad-white to -10.8 $\%$ BS-1 x Sahiwal-2002 and BP heterosis ranging from $0.0 \%$ to $-11.7 \%$, respectively. The cross Sahiwal-2002 x Sadaf and Sadaf x Islamabad-white took the highest number of days 50.0, 48.7 for $50 \%$ pollen shed. While the crosses Azam x Islamabad-white and Azam X Sahiwal-2002 pollen shed in minimum period of 45.0 and 45.3 days, respectively, whereas pollen shed in parents ranging from 45.0 to 51.7 days. The maximum days to $50 \%$ pollen shed in parents, Sadaf 51.7, while the minimum period 45.0 took by Azam. Researchers like Kumar and Gupta [5] and Dickers and Tracy [6] have also reported negative heterosis for the parameter discussed.

The data observed for $50 \%$ silking ranged from 0.7 to $-9.6 \%$ and 0.0 to $-9.8 \%$ against MP, BP heterosis as (Table 2) have also shown negative heterosis. The cross BS-1 x Sahiwal-2002 had the highest negative heterosis, MP and BP -9.7 and -9.8. Crosses involving Azam and BS-1 generally showed higher negative heterotic effect. Table. 2 showed that the highest value of 55.0 days to $50 \%$ silking for parental line for Sadaf and the minimum value 48.0 for Azam. On the other hand crosses showed variability ranging from 48.0 to 52.0 days. These results of [7-9] described useful crosses for $50 \%$ silking. Hence heterosis studies for $50 \%$ silking is not advisable

The estimation of heterosis and heterobeltiosis are presented in Table 2, indicating for plant height of 30 crosses, 28, and 21 crosses showed positive heterosis over their mid and better parental values, respectively. The magnitude of heterotic effect appeared to vary from -8.2 to $15.5 \%$ and $-10.7,10.3 \%$ against the mid and better parental values, so for as the plant height is concerned. The cross of Sadaf x Islamabadwhite had the highest value $15.5 \%$ for mid parent heterosis, and Islamabad-gold $\mathrm{x}$ Sadaf, $10.3 \%$ for better parent heterosis. As regards parental lines, the highest value of plant height, $195.1 \mathrm{~cm}$ and the lowest value of $161.0 \mathrm{~cm}$ were recorded in Sahiwal-2002 and Islamabad-white, respectively. While the crosses, Sadaf $\mathrm{x}$ BS-1, 210.0cm and Sahiwal-2002 x BS-1, 204.0cm resulted the tallest plant while shortest plants of $174.3 \mathrm{~cm}$ and $177.7 \mathrm{~cm}$ was shown by Sadaf x Sahiwal-2002, Islamabad-gold x Azam, respectively. In case of plant height tall $\mathrm{x}$ tall produced tall hybrids. However, the tallness parameter may or may not be beneficial. Because tallness may lead to lodging and consequently may declines the yield. However sometimes dwarf plant may produce prominent yield. In present studies mixed trend was noted, which is also supported by Ali et al. [10], Ali et al. [11] and Iqbal et al. [12].

Data for the trait under study showed heterosis of $16.0 \%$ and $13.8 \%$ in cross of Azam x Islamabad-gold for mid and better parent, respectively (Table 2). Out of 30 crosses, 18 showed positive heterosis over mid parent. Better parent heterosis estimates revealed the presence of such effect in 14 crosses, out of 30 crosses. The range of heterosis in crosses -11.5 to $16.0 \%$ and 14.6 to $13.8 \%$ against their mid and better parental values, respectively. The highest value for ears per plant was recorded in crosses, 1.2 and 1.0 for Azam x Islamabadgold and Islamabad-gold $x$ Azam, respectively. [13, 14] was also of same opinion for this character. The variation in estimated values of heterosis might be due to differences in cytoplasmic effects of the corresponding fertile hybrids

The degree of heterosis varied from cross to cross for ear length. Table 2 revealeds that the cross of BS-1 x Islamabad-gold had the highest values of heterosis $26.2 \%$ and heterobeltiosis $19.2 \%$ over their mid and better parental values, respectively, and 
closely followed by cross Islamabad-gold $\mathrm{x}$ Islamabad-white, 24.8, 20.8\% heterosis MP, $\mathrm{BP}$. The range of magnitude of heterotic effect among the crosses appeared to be from -12.6 to $26.2 \%$ and -17.5 to $20.8 \%$ against their mid and better parental values, respectively. Table 2 showed that the highest values $15.2 \mathrm{~cm}$ and $14.3 \mathrm{~cm}$ were observed in parental lines BS-1 and Sahiwal-2002. In case of crosses the highest ear length was recorded in cross BS-1 $\mathrm{x}$ Islamabad-gold and Islamabad-gold $\mathrm{X}$ Islamabad-white, $18.1,16.3 \mathrm{~cm}$, respectively. And the minimum ear length was recorded in cross Islamabad-white $\mathrm{x}$ Azam and Islamabad-white $\mathrm{x}$ Islamabad-gold 11.8 $11.5 \mathrm{~cm}$. These finding are in agreement with work quoted by Iqbal et al. [15] and Guimaraes and Souza [16].

Table 1. Estimation of mean squares and F. ratios at 35 and 105 D.F. analysis of variance for yield and others traits

\begin{tabular}{|l|c|c|c|c|}
\hline \multirow{2}{*}{ Parameters } & \multicolumn{3}{|c|}{ Mean Square } & \multirow{2}{*}{ F. Ratio } \\
\cline { 2 - 5 } & Replications & Genotypes & Error & \\
\hline Days to 50\% pollen-shed & 2.009 & 7.862 & 1.162 & $6.77^{* *}$ \\
\hline Days to 50\% Silking & 3.361 & 8.331 & 1.552 & $5.37^{* *}$ \\
\hline Plant height & 51.1 & 184.9 & 132.0 & $2.16^{* *}$ \\
\hline No of ears/plant & 0.009 & 0.008 & 0.004 & $0.007^{* *}$ \\
\hline Ear length & 2.612 & 5.214 & 1.516 & $3.44^{* *}$ \\
\hline No of kernel Rows/ear & 0.454 & 1.266 & 1.139 & $1.11^{\text {NS }}$ \\
\hline No of Kernels/row & 13.028 & 15.371 & 7.723 & $1.99^{* *}$ \\
\hline No of kernel/ear & 4515 & 3223 & 1770 & $1.82^{*}$ \\
\hline 1000 kernel weight & 169.70 & 591.60 & 319.40 & $1.85^{*}$ \\
\hline Grain yield & 656473 & 895004 & 307498 & $2.91^{* *}$ \\
\hline
\end{tabular}

Table 2. Estimation of heterosis (\%) and heterobeltiosis (\%) of various traits in $6 \times 6$ diallel cross of maize (Zea mays L.)

\begin{tabular}{|c|c|c|c|c|c|c|c|c|c|c|}
\hline \multirow[t]{2}{*}{ Crosses } & \multicolumn{2}{|c|}{$\begin{array}{l}\text { Days to } 50 \% \\
\text { pollen-shed }\end{array}$} & \multicolumn{2}{|c|}{$\begin{array}{l}\text { Days to } 50 \% \\
\text { silking } \\
\end{array}$} & \multicolumn{2}{|c|}{ Plant height } & \multicolumn{2}{|c|}{ No of ears/plant } & \multicolumn{2}{|c|}{ Ear length } \\
\hline & $\operatorname{Ht}(\%)$ & $\operatorname{Hbt}(\%)$ & $\operatorname{Ht}(\%)$ & $\operatorname{Hbt}(\%)$ & Ht(\%) & $\operatorname{Hbt}(\%)$ & Ht(\%) & $\operatorname{Hbt}(\%)$ & Ht(\%) & $\operatorname{Hbt}(\%)$ \\
\hline $\begin{array}{l}\text { Azam x Islamabad- } \\
\text { white }\end{array}$ & -3.2 & -6.2 & -2.0 & -4.6 & $6.5^{*}$ & $2.3^{*}$ & -4.0 & -8.0 & $11.7 *$ & $8.9 *$ \\
\hline $\begin{array}{l}\text { Azam x Sahiwal- } \\
2002\end{array}$ & -4.4 & -10.3 & -3.9 & -9.2 & 4.0 & -1.4 & 3.3 & 1.3 & 2.1 & -6.2 \\
\hline Azam x Sadaf & -3.4 & -9.6 & -1.6 & -7.8 & $5.3 *$ & $2.5^{*}$ & $4.2 *$ & 2.4 & $11.9 *$ & 7.7 \\
\hline $\begin{array}{l}\text { Azam x Islamabad- } \\
\text { gold }\end{array}$ & -1.8 & -4.2 & -2.7 & -4.6 & $7.1 *$ & $5.2 *$ & $16.0 * *$ & $13.8 * *$ & -1.6 & -7.1 \\
\hline Azam x BS-1 & -4.1 & -9.2 & -4.9 & -9.9 & 4.3 & -0.4 & $5.4 *$ & 3.7 & 1.2 & -9.4 \\
\hline $\begin{array}{l}\text { Islamabad-white } \mathrm{x} \\
\text { Azam }\end{array}$ & -0.3 & -3.4 & 0.0 & -2.6 & $14.4 * *$ & $10.0 * *$ & 3.4 & -0.9 & 3.7 & -6.2 \\
\hline $\begin{array}{l}\text { Islamabad-white x } \\
\text { Sahiwal-2002 }\end{array}$ & -5.3 & -8.4 & -3.8 & -6.7 & $9.0^{*}$ & -0.5 & -4.2 & -6.5 & $10.5^{*}$ & 4.0 \\
\hline $\begin{array}{l}\text { Islamabad-white x } \\
\text { Sadaf }\end{array}$ & -3.0 & -6.4 & -1.5 & -5.4 & $13.2 * *$ & $6.0^{* *}$ & -2.4 & -8.0 & $15.1 *$ & $13.6^{*}$ \\
\hline $\begin{array}{l}\text { Islamabad-white x } \\
\text { Islamabad-gold }\end{array}$ & -3.4 & -4.1 & -1.9 & -2.6 & $9.8^{*}$ & $3.8^{*}$ & 1.3 & -1.0 & $12.5^{*}$ & -5.3 \\
\hline $\begin{array}{l}\text { Islamabad-white } \mathrm{x} \\
\text { BS-1 }\end{array}$ & -2.3 & -4.6 & -1.5 & -4.3 & $7.6^{*}$ & -1.0 & 0.6 & -5.0 & 0.1 & -8.2 \\
\hline
\end{tabular}




\begin{tabular}{|c|c|c|c|c|c|c|c|c|c|c|}
\hline $\begin{array}{l}\text { Sahiwal-2002 x } \\
\text { Azam }\end{array}$ & -1.7 & -7.8 & 0.6 & -4.9 & $6.3^{*}$ & 0.7 & $5.9^{*}$ & $3.8^{*}$ & 7.1 & -1.4 \\
\hline $\begin{array}{l}\text { Sahiwal-2002 x } \\
\text { Islamabad-white }\end{array}$ & -2.6 & -5.8 & -1.9 & -4.9 & 4.6 & -4.4 & -6.5 & -8.7 & $11.1^{*}$ & 4.6 \\
\hline $\begin{array}{l}\text { Sahiwal-2002 x } \\
\text { Sadaf }\end{array}$ & -2.9 & -3.2 & -2.7 & -3.6 & $6.8^{*}$ & $3.8^{*}$ & -2.3 & -5.8 & 8.1 & 3.1 \\
\hline $\begin{array}{l}\text { Sahiwal-2002 x } \\
\text { Islamabad-gold }\end{array}$ & -4.7 & -8.4 & -3.8 & -7.4 & 4.8 & 0.9 & -3.5 & -3.5 & 6.9 & 3.9 \\
\hline $\begin{array}{l}\text { Sahiwal-2002 x } \\
\text { BS-1 }\end{array}$ & -6.2 & -7.1 & -5.2 & -5.5 & 5.4 & 4.6 & 3.6 & 0.0 & -6.0 & -8.7 \\
\hline Sadaf x Azam & -3.4 & -9.6 & -2.9 & -9.0 & 4.6 & 1.9 & $8.8^{*}$ & $6.9^{*}$ & -0.4 & -4.2 \\
\hline $\begin{array}{l}\text { Sadaf x Islamabad- } \\
\text { white }\end{array}$ & -2.3 & -5.8 & -2.2 & -6.0 & $15.5^{* *}$ & $8.1^{* *}$ & 1.2 & -4.6 & $17.8 * *$ & $16.2 * *$ \\
\hline $\begin{array}{l}\text { Sadaf x Sahiwal- } \\
2002\end{array}$ & -8.7 & -9.0 & -7.6 & -8.4 & -8.1 & -10.7 & 3.7 & 0.0 & 4.0 & -0.7 \\
\hline $\begin{array}{l}\text { Sadaf x Islamabad- } \\
\text { gold }\end{array}$ & -3.0 & -7.0 & -2.2 & -6.6 & 4.2 & 3.2 & $4.8^{*}$ & 1.0 & 7.2 & 5.1 \\
\hline Sadaf x BS-1 & -7.8 & -9.0 & -6.7 & -7.8 & $11.8 *$ & $9.5^{*}$ & -1.6 & -1.7 & 7.0 & -0.7 \\
\hline $\begin{array}{l}\text { Islamabad-gold x } \\
\text { Azam }\end{array}$ & -1.8 & -4.2 & -2.0 & -4.0 & 0.0 & -1.6 & $9.4^{* *}$ & $7.3^{*}$ & 3.8 & -2.0 \\
\hline $\begin{array}{l}\text { Islamabad-gold x } \\
\text { Islamabad-white }\end{array}$ & 0.6 & 0.0 & 0.6 & 0.0 & $9.3^{*}$ & $3.3^{*}$ & -3.9 & -6.2 & $24.8 * *$ & $20.8^{* *}$ \\
\hline $\begin{array}{l}\text { Islamabad-gold x } \\
\text { Sahiwal-2002 }\end{array}$ & -4.7 & -8.4 & -3.2 & -6.7 & 5.3 & 1.4 & -0.2 & -0.2 & -10.4 & -2.9 \\
\hline $\begin{array}{l}\text { Islamabad-gold x } \\
\text { Sadaf }\end{array}$ & -3.0 & -7.0 & -2.8 & -7.2 & $11.3^{*}$ & $10.2^{*}$ & $6.5^{*}$ & 2.6 & $9.7 *$ & $7.5^{*}$ \\
\hline $\begin{array}{l}\text { Islamabad-gold x } \\
\text { BS-1 }\end{array}$ & -5.1 & -7.9 & -2.8 & -6.2 & -4.5 & -7.2 & -0.3 & -3.8 & -12.6 & -17.5 \\
\hline BS-1 x Azam & -0.6 & -5.9 & -0.3 & -5.5 & 3.6 & -1.0 & 3.9 & 2.2 & 7.6 & -3.6 \\
\hline $\begin{array}{l}\text { BS-1 x Islamabad- } \\
\text { white }\end{array}$ & -5.7 & -7.9 & -4.7 & -7.4 & $7.1^{*}$ & -1.5 & -7.4 & -12.7 & -7.6 & -5.4 \\
\hline $\begin{array}{l}\text { BS-1 x Sahiwal- } \\
2002\end{array}$ & -10.8 & -11.6 & -9.7 & -9.8 & 2.0 & 1.2 & $9.3^{* *}$ & $5.4^{*}$ & -3.4 & -6.2 \\
\hline BS-1 x Sadaf & -7.8 & -9.0 & -7.9 & -9.0 & 2.1 & 0.1 & $7.6^{*}$ & $7.5^{*}$ & 2.3 & -5.0 \\
\hline $\begin{array}{l}\text { BS-1 x Islamabad- } \\
\text { gold }\end{array}$ & -5.1 & -7.9 & -4.8 & -8.0 & $6.8^{*}$ & $3.7 *$ & -11.5 & -14.6 & $26.2 * *$ & $19.2^{* *}$ \\
\hline
\end{tabular}

The magnitude of the highest values for heterosis $(9.1,7.7 \%)$ Sahiwal-2002 x Islamabad-white for their mid and better parent heterosis, respectively (Table 3). Similarly 15 crosses showed positive heterosis over better parent. Maximum percentage of better parent heterosis (7.7) was shown by Sahiwal-2002 x Islamabadwhite. As evident in Table 3 the highest values for kernel row per ear was recorded in crosses Azam $\mathrm{x}$ Islamabad-gold, Islamabad-gold x Azam, 14.7, 14.7, respectively. And the lowest values, Sadaf $x$ Sahiwal-2002, 12.7. Among parental lines gave the highest value 14.00 by Azam, and the lowest value 12.66 by Islamabad-white. Investigation regarding heterosis and heterobetiosis are presented in Table 3. Study indicated that the cross of Azam $x$ Sadaf had the highest value for heterosis over mid parent $18.5 \%$, and BS-1 x Islamabad-gold for heterosis over better parent $16.8 \%$. The degree of heterosis effect appeared to range from -8.7 to $18.5 \%$ and 11.6 to $16.8 \%$ against the mid and better parental values so for as kernels per row are concerned. As revealed from Table 3 cross Islamabad-white x Sahiwal-2002 showed highest value for kernels per row 36.0, closely followed by 35.0 noted for Sahiwal- 
2002 x BS-1. In parental line Sahiwal-2002, that showing the highest value of 32.3 followed by Islamabad-white with the value of 31.7 , indicated variability among crosses and parental lines. The smallest value for kernel per row 28.0 was recorded in crosses Islamabad-white $\mathrm{x}$ Islamabad-gold. While the smallest value for a parental line was recorded as 23.0 for Azam. These findings are in agreement with the work reported by Moneam et al. [17] and Turi et al. [18]. For number of kernels ear ${ }^{-1}$, the magnitude of the highest values of heterosis was $22.8 \%$ and $21.4 \%$ BS-1 x Islamabad-gold over their mid and better parental values respectively. And closely followed by Sahiwal-2002 x Azam and Sahiwal-2002 x Islamabad-gold, $22.7,22.1 \%$ and $13.1,18.6 \%$ over their mid and better parental heterosis. The degree of heterotic effect appeared to range from, -7.0 to $22.8 \%$ and -9.9 to $21.4 \%$ against the mid and better parental values so for as grains ear $^{-1}$ concerned. Table 3 showed the highest value 447.7 for parent Islamabad-white. In case of crosses, 510.3 and 498.3, BS- 1 x Islamabad-gold and Sahiwal-2002 $x$ Islamabad-gold, respectively. The lowest 334.3 value was recorded in Azam. Lowest

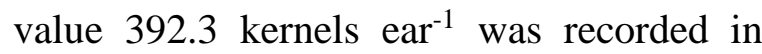
cross, Islamabad-gold $\mathrm{x}$ Azam. For the parameter 1000-grain weight the cross of Islamabad-white x Sadaf had the highest value for heterosis $19.4 \%, 19.2 \%$ over their mid and better parental values respectively (Table 3). The range of heterotic effect appeared to vary from -3.9 to $19.5 \%$ and 6.8 to $19.2 \%$ against the mid and better parental values, respectively so for as the 1000 -seed weight is concerned. These finding are in consistency with those reported by Iqbal et al. [19] and Guimaraes and Souza [16].

The cross of Islamabad-white $x$ Sadaf for grain yield $\mathrm{kg} \mathrm{ha}^{-1}$ had the highest value for heterosis $51.3 \%$ and $48.0 \%$ over mid and better parental values, respectively (Table 3). It was closely followed by Azam x Islamabad-white, $47.8 \%$ and $44.1 \%$ for mid and better parental values. The range of heterotic effect appeared to vary from -16.2 to $51.3 \%$ and -27.2 to $48.0 \%$ against the mid and better parental values respectively so for the yield $\mathrm{kg} \mathrm{ha}^{-1}$ is concerned. Table 3 showed that the highest values of crosses of grain yield $\mathrm{kg}$ per ha 5175.0 and 5040.6 for Islamabad-gold x Sahiwal-2002 and Sadaf x Islamabad-gold, respectively, and minimum values 3150.67, 3611.33 for crosses Azam x Sadaf and BS-1 $x$ Islamabad-white, respectively. On the other hand parental lines showed variability ranging from 3190.3 to 4720.6 . Among parental lines the highest value for grain yield $\mathrm{kg} \mathrm{ha}^{-1}, 4720.6$ by Sahiwal-2002 and the minimum value 3190.3 by Islamabad-white for the grain yield $\mathrm{kg} \mathrm{ha}^{-1}$. These results are supported by the findings of Guimaraes and Souza [16], Khalil et al. [20]. The overall performance of crosses Islamabad-gold x Sahiwal-2002 and Sadaf $x$ Islamabad-gold were commendable and if these are included in breeding schemes it might be proved as potent hybrids . Hence further exploration in maize for the production of hybrids it is suggested that theses inbred lines as well as their cross combination should be focused to get the optimal and desirable results. 
Table 3. Estimation of heterosis (\%) and heteobeltiosis (\%) of various characters in $6 \mathrm{x}$ 6 diallel cross of maize (Zea mays L.)

\begin{tabular}{|c|c|c|c|c|c|c|c|c|c|c|}
\hline \multirow[t]{2}{*}{ Crosses } & \multicolumn{2}{|c|}{$\begin{array}{l}\text { No of kernel } \\
\text { Rows/ear }\end{array}$} & \multicolumn{2}{|c|}{$\begin{array}{l}\text { No of } \\
\text { Kernels/row }\end{array}$} & \multicolumn{2}{|c|}{ No of kernel/ear } & \multicolumn{2}{|c|}{$\begin{array}{l}\text { 1000-grain } \\
\text { weight }\end{array}$} & \multicolumn{2}{|c|}{ Grain yield } \\
\hline & $\operatorname{Ht}(\%)$ & $\operatorname{Hbt}(\%)$ & Ht $(\%)$ & $\operatorname{Hbt}(\%)$ & Ht(\%) & $\operatorname{Hbt}(\%)$ & $\mathrm{Ht}(\%)$ & $\operatorname{Hbt}(\%)$ & Ht $(\%)$ & Hbt $(\%)$ \\
\hline $\begin{array}{l}\text { Azam x Islamabad- } \\
\text { white }\end{array}$ & $5.0 *$ & 0.0 & $9.6^{*}$ & -4.2 & $11.3^{*}$ & -2.8 & 5.6 & 0.2 & $47.8 * *$ & $44.1 * *$ \\
\hline Azam x Sahiwal-2002 & 1.2 & -4.7 & $8.3^{*}$ & -6.2 & $15.0 * *$ & $6.0 * *$ & -2.8 & -3.6 & $12.0^{*}$ & -4.1 \\
\hline Azam x Sadaf & 4.7 & -4.7 & $18.5 * *$ & $5.5^{*}$ & $16.6 * *$ & $3.8^{*}$ & -0.3 & -5.3 & 7.9 & $7.5^{*}$ \\
\hline $\begin{array}{l}\text { Azam x Islamabad- } \\
\text { gold }\end{array}$ & $7.3^{*}$ & $4.7 *$ & $10.0^{*}$ & -1.1 & $14.9 *$ & $3.2^{*}$ & -3.9 & -4.7 & $14.6^{*}$ & 3.8 \\
\hline Azam x BS-1 & -2.4 & -4.7 & $11.4 *$ & 1.1 & $9.8^{*}$ & -0.3 & $6.7 *$ & $3.4^{*}$ & 4.0 & -7.6 \\
\hline $\begin{array}{l}\text { Islamabad-white } \mathrm{x} \\
\text { Azam }\end{array}$ & $5.0^{*}$ & 0.0 & $13.5 * *$ & -1.0 & $13.2 *$ & -1.1 & -1.7 & -6.8 & $21.4^{*}$ & 18.4 \\
\hline $\begin{array}{l}\text { Islamabad-white x } \\
\text { Sahiwal-2002 }\end{array}$ & -1.9 & -2.5 & $12.5^{*}$ & $11.3 * *$ & $9.0^{*}$ & 2.7 & -0.8 & -5.2 & 1.3 & -15.0 \\
\hline $\begin{array}{l}\text { Islamabad-white } \mathrm{x} \\
\text { Sadaf }\end{array}$ & -5.0 & -9.5 & $9.7 *$ & $7.3^{*}$ & 4.2 & 2.0 & $19.5^{* *}$ & $19.2 * *$ & $51.3 * *$ & $48.0 * *$ \\
\hline $\begin{array}{l}\text { Islamabad-white x } \\
\text { Islamabad-gold }\end{array}$ & $7.9^{*}$ & 5.0 & -8.9 & -1.5 & -7.1 & -9.9 & $11.8^{*}$ & $6.8^{*}$ & $27.0 * *$ & $12.4^{*}$ \\
\hline $\begin{array}{l}\text { Islamabad-white } \mathrm{x} \\
\text { BS-1 }\end{array}$ & -2.6 & -5.0 & 2.9 & -2.1 & -4.6 & -8.7 & $11.7^{*}$ & $9.4^{*}$ & $20.6 * *$ & 4.8 \\
\hline Sahiwal-2002 x Azam & 3.7 & 0.0 & $9.5^{*}$ & -5.1 & $22.6 * *$ & $13.1 * *$ & -0.8 & -1.6 & 5.5 & -9.6 \\
\hline $\begin{array}{l}\text { Sahiwal-2002 x } \\
\text { Islamabad-white }\end{array}$ & $9.1 * *$ & $7.6^{* * *}$ & 2.1 & 1.0 & $11.3^{*}$ & $4.9^{*}$ & $12.0^{*}$ & $7.1^{*}$ & $10.1 *$ & -7.7 \\
\hline Sahiwal-2002 x Sadaf & -6.7 & -9.5 & $9.5^{*}$ & $6.2^{*}$ & $15.1 * *$ & $10.7 * *$ & 3.9 & -0.5 & $11.5^{*}$ & -4.8 \\
\hline $\begin{array}{l}\text { Sahiwal-2002 x } \\
\text { Islamabad-gold }\end{array}$ & $6.3^{*}$ & $5.0^{*}$ & $7.5^{*}$ & 3.1 & $22.1 * *$ & $18.5^{* *}$ & -1.5 & -1.6 & $11.2 *$ & 4.5 \\
\hline Sahiwal-2002 x BS-1 & -3.9 & -5.0 & $14.1 * *$ & $8.2^{*}$ & $16.5 * *$ & $14.5^{* * *}$ & 3.5 & 1.0 & $8.8^{*}$ & 4.3 \\
\hline Sadaf x Azam & 0.0 & 0.0 & $12.3^{*}$ & 0.0 & $16.6 * *$ & $3.8^{*}$ & 2.2 & -2.9 & $30.6 * *$ & $30.2 * *$ \\
\hline $\begin{array}{l}\text { Sadaf x Islamabad- } \\
\text { white }\end{array}$ & 0.0 & -4.7 & -2.2 & -4.2 & -2.3 & -4.4 & $12.9^{*}$ & $12.7^{*}$ & $32.8 * *$ & $29.9 * *$ \\
\hline Sadaf x Sahiwal-2002 & -6.7 & -9.5 & 3.2 & 0.0 & 3.5 & -0.5 & $7.8^{*}$ & 3.3 & $23.3 *$ & 5.2 \\
\hline $\begin{array}{l}\text { Sadaf x Islamabad- } \\
\text { gold }\end{array}$ & -7.3 & -9.5 & $5.5^{*}$ & $4.4^{*}$ & 4.1 & 3.1 & $10.7 *$ & $6.0^{*}$ & $34.7 * *$ & $21.6^{*}$ \\
\hline Sadaf x BS-1 & -7.3 & -9.5 & -6.7 & -8.8 & -0.7 & -2.8 & $9.7 *$ & $7.6^{*}$ & -3.1 & -14.2 \\
\hline $\begin{array}{l}\text { Islamabad-gold x } \\
\text { Azam }\end{array}$ & $7.3^{*}$ & $4.7 *$ & $16.2 * *$ & $4.5^{*}$ & 3.9 & -6.6 & -0.6 & -1.3 & $24.6^{*}$ & $12.8^{*}$ \\
\hline $\begin{array}{l}\text { Islamabad-gold x } \\
\text { Islamabad-white }\end{array}$ & $7.7 *$ & $5.0^{*}$ & 1.1 & -2.1 & $8.9 *$ & 5.6 & 5.8 & 1.1 & 13.6 & 0.5 \\
\hline $\begin{array}{l}\text { Islamabad-gold } \mathrm{x} \\
\text { Sahiwal-2002 }\end{array}$ & $6.3^{*}$ & $5.0^{*}$ & 4.3 & 0.0 & $13.1^{*}$ & $9.8^{*}$ & $9.6^{*}$ & $9.6^{*}$ & $16.7 *$ & $9.6^{*}$ \\
\hline $\begin{array}{l}\text { Islamabad-gold x } \\
\text { Sadaf }\end{array}$ & -2.4 & -4.7 & $8.8^{*}$ & $7.7 *$ & 6.9 & $5.9^{*}$ & -1.3 & -5.6 & $13.1^{*}$ & 2.0 \\
\hline $\begin{array}{l}\text { Islamabad-gold x BS- } \\
1\end{array}$ & 0.0 & 0.0 & $6.8^{*}$ & $5.6^{*}$ & 0.4 & -0.7 & 2.4 & -0.1 & -14.1 & -15.9 \\
\hline BS-1 x Azam & $7.3^{*}$ & $4.7^{*}$ & $17.7 * *$ & $6.8^{*}$ & $21.8 * *$ & $10.5^{* *}$ & 1.5 & -1.7 & -0.2 & -11.4 \\
\hline $\begin{array}{l}\text { BS-1 x Islamabad- } \\
\text { white }\end{array}$ & 2.5 & 0.0 & 2.2 & -2.1 & -2.4 & -6.5 & $7.8^{*}$ & $5.5^{*}$ & -16.1 & -27.1 \\
\hline BS-1 x Sahiwal-2002 & $6.3 *$ & $5.0 *$ & 3.3 & -2.1 & $12.5^{*}$ & $10.5 * *$ & $16.0 * *$ & -4.5 & -14.4 & -17.9 \\
\hline BS-1 x Sadaf & -7.4 & -9.5 & 3.4 & 1.1 & -4.0 & -6.0 & $16.0^{* * *}$ & $13.8 * *$ & 0.8 & -10.7 \\
\hline $\begin{array}{l}\text { BS-1 x Islamabad- } \\
\text { gold }\end{array}$ & $5.0^{*}$ & $5.0 *$ & $18.2 * *$ & $16.8 * *$ & $22.8 * *$ & $21.4 * *$ & -2.1 & 13.2 & $9.7^{*}$ & $7.4^{*}$ \\
\hline
\end{tabular}




\section{Conclusion}

It is concluded from the present research work that the magnitude of heterosis and heterobeltiosis in all the studied traits showed that these inbred lines are fruitful for further breeding purpose in maize hybrids production.

\section{Authors' contributions}

Conceived and designed the experiments: S Ali \& S Khan, Performed the Experiments: S Ali, Analyzed the Data: S Ali, AI Shah, Contributed reagents/ materials/ analysis tools: S Khan, Wrote the paper: S Ali, A Jamil \& M Waqas.

\section{Acknowledgment}

The author is so thankful to Mr. Arshad Jamil and Mr. Asif Imran Shah for the composing, technical analysis and scientific writing for this scientific manuscript. I am so pleased to Mr. Habib Ullah and the entire staff of ARI DIKhan for their cooperation during the research work

\section{References}

1. Ali W, Rahman H, Ahmad K, Munir I \& Khan A (2007). Genetic variability among maize hybrids for yield and yield components. Sarhad J Agriculture 23(1): 75-79.

2. Fehr WR (1987). Heterosis: Principles of Cultivars Development. Macmillan Publishing Company Inc New York (1): 115-119.

3. Fonseca M (1965). Heterosis, Heterobeltiosis, diallel analysis and gene action in crosses in Triticum L. Ph. D thesis Purdue Uni USA.

4. Fehr WR (1987). Heterosis: Principles of Cultivars Development. Macmillan Publishing Company Inc New York (1): 115-119.

5. Kumar P \& Gupta S (2004). Genetic analysis in maize (Zea mays L.). $J$ Res Birsa Agri Univ (16): 113-117.

6. Dickers TE \& Tracy WF (2002). Heterosis for flowering time and agronomic traits among early open- pollinated sweet corn cultivars. $J$ American Society Hort Science (127): 793-797.

7. Kumar P \& Gupta S (2004). Genetic analysis in maize (Zea mays L.). J Res Birsa Agri Univ (16): 113-117.

8. Dickers TE \& Tracy WF (2002). Heterosis for flowering time and agronomic traits among early openpollinated sweet corn cultivars. $J$ American Society Hort Science (127): 793-797.

9. Amanullah, Jehan S, Mansoor M \& Khan MA (2011). Heterosis studies in diallel cross of maize. Sarhad J Agriculture 27(2): 207-211.

10. Ali S, Rahman H, Raziuddin, Shah SS \& Hassan G (2006). Estimate of variability, heritability and genetic advance for fodder traits in two maize populations. Pakistan J Biol Science 9(14): 26182623.

11. Ali W, Rahman H, Ahmad K, Munir I \& Khan A (2007). Genetic variability among maize hybrids for yield and yield components. Sarhad J Agriculture 23(1): 75-79.

12. Iqbal M, Khan $K$, Rahman $H$ \& Sher $H$ (2010). Detection of epistasis for plant height and leaf area in Maize. (Zea mays L.) from generation mean analysis. Maydica (55): 33-39.

13. Saleh GB, Abdullah D \& Anwar AR (2002). Performance, heterosis and heritability in selected tropical maize single, double and three-way cross hybrids. $J$ Agricculture Science (138): 21-28.

14. Amanullah, Jehan S, Mansoor M \& Khan MA (2011). Heterosis studies in diallel cross of maize. Sarhad $J$ Agriculture 27(2): 207-211.

15. Iqbal M, Khan K, Rahman H \& Sher H (2010). Detection of epistasis for plant height and leaf area in Maize. (Zea mays 
L.) from generation mean analysis. Maydica (55): 33-39.

16. Guimaraes \& Souza PD (2007). Correlation between the heterosis of maize hybrids and genetic divergence among lines. Pesq Agropec Bras (42): 811-816.

17. Moneam A, Attia AN, Emery MIE \& Fayed EA (2009). Combining ability and heterosis for some agronomic traits in crosses of maize. Biol Science (12): 433438.

18. Turi, NA, Shah SS, Ali S, Rahman H, Ali T \& Sajjad M (2007). Genetic variability for yield parameters in maize genotypes. J Agriculture \& Biol Sceince (2): 4-5.

19. Iqbal M, Khan K, Rahman H \& Sher H (2010). Detection of epistasis for plant height and leaf area in Maize. (Zea mays L.) from generation mean analysis. Maydica (55): 33-39.

20. Khalil, IA, Rahman H, Seed N, Durreshawar, Nawaz I, Ali F, Khan N, Sajjad M \& Saeed M (2010). Combining ability in maize single cross hybrids for grain yield: a graphical analysis. Sarhad J Agriculture 26(3): 373-379. 